\title{
REBUILDING THE PROFESSIONAL TEACHING CAPACITY OF UNDERGRADUATE ENGLISH EDUCATION STUDENTS OF UIN ALAUDDIN MAKASSAR (A Case Study on Student-Teachers of PBI Students of Tarbiyah Faculty)
}

\author{
Mardiana Nurdin \\ Fakultas Tarbiyah dan Keguruan UIN Alauddin Makassar \\ Kampus II: Jalan Sultan Alauddin Nomor 36 Samata-Gowa \\ Email: diana.syahrir69@gmail.com
}

\begin{abstract}
Abstrak:
Penelitian ini bertujuan untuk mengeksplorasi kapasitas pengajaran yang profesional mahasiswa PPL PBI UIN Alauddin Makassar yang melibatkan 4 guru pamong dan 30 mahasiswa PPL. Data dikumpulkan melalui survei online, lembar pengamatan dan dokumentasi yang dianalisis dengan menggunakan metode campuran qualitatif dan kuantitatif. Penelitian ini menyimpulkan bahwa: 1) mahasiswa PPL berpendapat bahwa seorang guru bahasa Inggris seharusnya mampu melakukan tanggung jawabnya sebagai seorang guru yang memiliki kompetensi paedagogik, profesional, sosial, dan kepribadian, 2) mahasiswa PPL cenderung menerima pebelajar mandiri, kerja berpasangan dan kerja kelompok, mengadaptasi pengajaran untuk memenuhi kebutuhan siswa sebelum praktik pembelajaran, tetapi cenderung menguranginya selama proses pembelajaran; mahasiswa PPL juga cenderung menerima pengajaran grammar secara eksplisit, koreksi kesalahan, dan pengucapan seperti penutur asli, pengetahuan teknikal, dan keterampilan interpersonal sebelum praktik mengajar dan meningkatkan proporsinya selama proses mengajar, 3) Guru pamong berpendapat bahwa mahasiswa PPL PBI UIN alauddin harus meningkatkan kemampuan bahasa Inggris, penggunaan metode pengajaran yang inovatif, penilaian autentik, dan penggunaan media yang bervariasi.
\end{abstract}

\begin{abstract}
:
This research aims to explore the professional teaching capacity of undergraduate English education students of UIN Alauddin Makassar. It involves 4 supervisingteachers and 30 student-teachers. The data were collected through online survey questionnaires, feedback observation sheets and documentation; analyzed quantitatively and qualitatively. The research finds that: 1) the student-teachers perceive an EFL teacher should be able to do their responsibilities which involves pedagogic, professional, social, and personal competences; 2) the student-teachers have a tendency to accept learner autonomy, pair/group work, adapting teaching to cater for learner needs before the teaching-practice but tend to decrease some parts of it during the teaching-practice; the student-teachers are likely to accept explicit grammar instruction, error correction and native like pronunciation, technical knowledge and interpersonal skills before the teaching-practice and increase the proportion of them during the teaching-practice; 3) The supervising-teachers considered that the student-teachers of PBI UIN Alauddin Makassar still need to improve their English speaking ability, the use of innovative EFL teaching methods and authentic assessment and the use of different kind of teaching media.
\end{abstract}

Kata kunci:

Perception, student-teachers, teaching-practice, EFL teachers, roles 
ENGLISH education system in Indonesia continues to evolve and impact on future English education service delivery. As many factors currently influence the reform of English education system in Indonesia, this study explores perception and experience of the students of Jurusan Pendidikan Bahasa Inggris of UIN Alauddin Makassar (henceforth PBI) of the work of English teachers before and after finishing the teachingpractice in the seventh semester. These perceptions and experiences combined with their prior knowledge they have acquired through the courses of English teaching in six semesters are used as initial data in the attempt to rebuild the professional teaching capacity of the students of PBI.

The course of PBI is commonly identified as a mixed-program of theory and practice in English teacher education program. The course is administered in eight semesters with each semester the student-teachers are directed to develop their theoretical knowledge in teaching English. In the seventh semester, the studentteachers are administered to develop their reflective practitioners as student-teachers after practicing teaching for about six months in certain junior or senior high schools. Supervising-teachers at the teaching-practice schools together with tutor-lecturers play a key role in the professional preparation of student-teachers. Throughout each teaching-practice, supervising teachers and tutor-lecturers will enhance the development of student-teachers by providing effective supervision, assistance to the studentteachers, duty-of-care and early identification of student-teachers at-riskiness.

The role of PBI educators is to facilitate the ways in which student-teachers build new knowledge and understanding of their roles as language teachers. Since the regulation of the Ministry of Education and Cultures of Republic of Indonesia Number 87 of 2013 about the Program Pendidikan Profesi Guru or Pre-service Teacher Professional Education Program (henceforth PPG) is issued in August 2013, this unit is becoming more aware of the increasing challenge towards the placement of its outcomes and PBI educators are now facing a greater challenge to escort studentteachers competing when entering the real world of teaching. It was acknowledged that PPG was one of many issues impacting on the university in preparing the student-teachers and could not be addressed in isolation. Conferring that it is important to articulate standards of attitude, knowledge and skill competence for studentteachers education, it is equally critical to consider how best to prepare the course of PBI for future challenges. Thus, the focus questions are as follows:

1. What perceptions do the student-teachers of PBI have on the roles and responsibilities of English language teachers before and after the teaching-practice?

2. What aspects of the English language teachers' roles at the teaching-practice schools which the student-teachers of PBI accept and/or reject?

3. What perceptions do supervising teachers have on the student-teachers of PBI during the teaching-practice in their schools? 


\section{LITERATURE REVIEW}

\section{Roles and Responsibilities of EFL Teachers}

Concept of role is rooted in Behaviorism and expanded into social studies which mainly used by the symbolic interactionism theory. In some sociology literatures, role is defined as a prescribed or expected behavior associated with a particular position or status in a group or organization. Dörnyei and Murphey point out that 'role' is a technical term which originally comes from sociology and refers to the shared expectation of how an individual should behave. In other words, roles describe what people are supposed to do. ${ }^{1}$ Christiansen and Baum define 'role' as a set of behaviors that have some socially agreed-upon functions and an accepted code of norms. ${ }^{2}$ In English Language Teaching (ELT), several methodologists (Littlewood, Richards and Rodgers, Tudor, and Harmer) have discussed many potential roles for a language teacher. Richards and Rodgers consider teacher roles as part of the 'design' component of a method, pointing out that these are related to the issues the types of function teachers are expected to fulfill, the degree of control the teacher has over how learning takes place and the degree to which the teacher is responsible for determining the content of what is taught and the interactional patterns that develop between teachers and learners. ${ }^{3}$ Littlewood conceptualizes the role of the language teacher broadly as the learning facilitator in the context of Communicative Language Teaching (CLT) instead of the rather narrow concept of the teacher as instructor. ${ }^{4}$ Harmer looks at the term facilitator in a much broader way than Littlewood does, and points out that the ultimate aim of all roles is to facilitate the students' progress in some way or the other. ${ }^{5}$ Tudor looks at the role of the teacher in the context of the notion of the learnercentered classroom, a kind of classroom in which the focus is on the active involvement of the learners in the learner process. ${ }^{6}$

In Indonesia, where English is the prime foreign language to be learned by students at schools, the roles and responsibilities of the English teachers are rules and regulated by the government and the EFL teaching related associations of Indonesia. The common core standards (CCS) of English teachers in Indonesia are regulated by the Act Number 20 of 2003 about National Education System (UU No. 20 Tahun 2003 tentang Sistem Pendidikan Nasional) and the Act Number 14 of 2005 about Teachers and Lecturers (UU No. 14 Tahun 2005 tentang Guru dan Dosen). In the Act Number 14 of 2005 on Teachers and Lecturers, as a follow-up to the Act Number 23 of 2003 on the National Education, it is explained that the teachers are professional educators with the primary task of educating, teaching, guiding, directing, training, assessing, and evaluating students in early childhood education of formal education, primary education, and secondary education (Article 1, Paragraph 1), with the position as professional staff in primary education, secondary education, and early childhood education of formal education were appointed in accordance with the legal law (Article 2, Paragraph 1) and verified by a certificate of professional (Article 2, Paragraph 2). Teacher professionalism is shown by various principles of professionalism (Chapter III, Article 7) and qualifications, competencies and certification (Chapter IV Articles 8-13). ${ }^{7}$ 
Studies of roles and responsibilities of English teachers have been widely carried out by many scholars all over the world. To mention one, Aberg and Waller (2012) carried out a descriptive study of English teaching in Jamaica, and examined what perceptions upper secondary school teachers have of the teaching mission, the teacher role and the responsibility that comes with the teacher profession. They also examined the teachers' attitudes towards Jamaican Creole and Standard Jamaican English and the relation between these two languages. ${ }^{8}$ Another study is carried out by Choudury who looks at the classroom roles of English language teachers in the second language/foreign language context with particular reference to the Indian one. ${ }^{9}$

\section{Perception and Beliefs in Language Teaching}

In the classroom context according to Breen ${ }^{10}$, the perceptions, beliefs, attitudes, and metacognitive knowledge that students bring with them to the learning situation have been recognized as a significant contributory factor in the learning process and ultimate success. The constructivist view of learning underpins the establishment of PBI program which is rooted in the idea that students exploit their previous knowledge and accommodate new comprehension within an existing framework of knowledge. The establishment of teaching-practice in the seventh semester of PBI is to promote student-teachers' ability to reflect on their own practice regularly and effectively. The aims include the development of skills of "reflecting-in-action", in particular, during teaching rounds, and "reflecting-on-action" in some teaching methodology lectures where students are invited to assimilate new input into their prior conceptions of language teaching and learning. ${ }^{11}$ According to Brown and McGannon the basis for the promotion of reflective approaches in pre-service programs is the argument that Kyriacou makes that initial teacher training cannot possibly produce prospective teachers who know all they need to get ideas about classroom practice. A number of researchers (e.g. Joram and Gabriele, 1998; Bruner, 1996) have discussed the need to study pre-service teachers' prior beliefs and to take them into account when teaching. Prospective EFL teachers have well developed beliefs about teaching and learning languages. These beliefs constitute what has been dubbed "folk pedagogies"12 or personal history based language theories ${ }^{13}$ meaning that student-teachers experiences as language learners and in most cases as language teachers, make up an "apprenticeship of observation". Kwo's study of studentteachers lends support to Kagan's model. Kwo collected data on a group of English language student-teachers from the University of Hong Kong during a teaching practice period. The study found that this was a high stress period for students, a time during which they clung to planned routines and highly structured classes even though they saw flexibility and more student-centered teaching as desirable. ${ }^{14}$ Further exploration of the way in which students learn to teach during teaching practice is clearly needed.

\section{Knowledge, Ability, and Experience in Language Teaching Practices}

Knowledge, ability and experience are three of the listed special qualifications and personal attributes that a teacher needs to practice her/his job. Knowledge in 
language teaching practice is a statement that refers to an organized educational body of information usually of a factual or procedural nature which, if applied, makes adequate performance on the job possible. Ability refers to the power to perform an observable activity at the present time. ${ }^{15}$ Furthermore, Reinmann states that the knowledge, skills, abilities and attitudes which teachers need to have in order to promote learning processes and design lessons is called teaching proficiency. In this context 16 , Duxa talks about "the ability to act in a way that is appropriate to a specific situation". ${ }^{17}$

Hattie helps describe this teaching proficiency as the teachers' openness to experience, learning from errors, seeking and learning from students' feedback and fostering effort, clarity and engagement in learning". 18 For the purpose of understanding ability of teaching languages, Schart and Legutke present three ways in which to develop this kind of reflection ability, namely combine theory and practice using the knowledge that comes with experience, explore their own classroom, and plan and implement practical research projects. ${ }^{19}$ Vineberg and Taylor have conducted four independent studies which are applicable in job of teaching related area. They examined the causal impact of job experience on job knowledge, performance capability as measured by job sample tests, and supervisory ratings of job performance. ${ }^{20}$ Ministry of Education and Cultures together with the Ministry of Religious Affairs for tertiary education have repeatedly emphasized the need for welltrained teachers and promoted such projects in the PPG program mandated by regulation issued by the Minister of Education and Culture Number 87 of 2013 about Program Pendidikan Profesi Guru Prajabatan (Pre-service Teacher Profession Education). In Article 9 (1), it is stated:

Struktur kurikulum program PPG berisi lokakarya pengembangan perangkat pembelajaran, latihan mengajar melalui pembelajaran mikro, pembelajaran pada teman sejawat, Program Pengalaman Lapangan (PPL), dan program pengayaan bidang studi dan/atau pedagogi.

The verse of the article contains the orientation of the PPG program on providing well-trained teachers that is accommodated in the curriculum structure, learning system, and the workshop implementation. In Verse 1, the curriculum structure consists of teaching preparation, micro teaching, peer teaching, real teaching, and content area and pedagogic enrichment. ${ }^{21}$ The achievement target of the PPG program for the pre-service teachers is in line with Brown and McGammon's (1999) statement that the task of language teacher educators is to probe students' conceptions about language teaching and learning to help them to make connections between their prior experiences as language learners and teachers and the experiences in language classrooms and in TESOL methodology class. ${ }^{22}$

The teacher educator's role is to facilitate the ways in which student-teachers build new knowledge and understanding of their roles as language teachers. ${ }^{23}$ Shulman ${ }^{24}$ has called for teacher-educators to help learners make implicit knowledge explicit through reflection upon practical experience and theoretical understanding. 
Bruner argues that it is essential that teacher educators take prior beliefs into account because any new material taught will have to compete with, or replace or otherwise modify the folk theories that already guide both teachers and students. ${ }^{25}$ Freeman suggests that what teachers already know about teaching is "minimally affected by what they encounter in their professional education" ${ }^{26}$

\section{Conceptual Framework}

PBI as a contributor of future professional English language teachers has currently reviewed its curriculum to meet the requirements of the national standards of teacher tertiary education in Indonesia. The issue of PPG regulation has added to the increasing challenge towards the placement of PBI outcomes since they have to compete against other scholars from non-education discipline background entering the real world of teaching. To maintain the PBI position as a contributor of future professional English teachers, it is important to equip PBI students with pre-service program of foreign language teacher or commonly called teaching-practice. An important part of pre-service foreign language teacher education is the shift from student as learner to student as teacher. Part of this shift involves identification with and self-perception as teacher through an understanding of the roles and responsibilities of language teachers as enacted by both supervising-teachers and by the beginning teachers themselves. Research and theories of perception and beliefs in language learning maintained that students' beliefs about learning and teaching, whether explicit or implicit, affect everything they do in classrooms. Thus, in the case of pre-service foreign language teachers, what perceptions do the student-teachers of PBI have on the roles and responsibilities of English language teachers? What are the interpretations placed on this role which student-teachers accept? What aspects of the enacted role do they reject? What are the personal characteristics, beliefs and experiences which these beginning teachers bring to initial teaching experiences? How do these individual understandings influence the growing identification with other more experienced language teachers?

\section{RESEARCH METHOD}

This study mainly aims to develop concepts of strategy in rebuilding the capacity of PBI to provide competent and professional EFL teachers through the explanation and interpretation of the emergent perceptions, beliefs and experiences of the student-teachers of PBI of the work of English teachers before and after finishing their teaching-practice and how they made link with their prior knowledge. This study used a combination of quantitative and qualitative approach or a mixedmethod research. Creswell suggest the use of a mixed-method with philosophical assumptions as well as methods of inquiry. ${ }^{27}$ Creswell offers six strategies of mixedmethod design and for this current study it was decided to use sequential explanatory. Sequential explanatory is characterized by a collection and analysis of quantitative data followed by a collection and analysis of qualitative data. The 
purpose is to use qualitative results to assist in explaining and interpreting the findings of a quantitative study. ${ }^{28}$

The data gathering of this research was done through the online-survey questionnaire before the teaching-practice period early in July 2014 and during the teaching-practice of the first month session from August to September 2014. Feedback observation on the student-teachers' teaching-practice collected from the supervisingteacher was completed in September 2014. This research was carried out in campus, online, and in the three training-schools located in Makassar.

The data of this research were related to the research focus and subfoci either primary or secondary. The primary data were the statements of the respondents, in this case the student-teachers, supervising-teachers and the head of department of PBI. Secondary data were written or scripted documents from relevant resources. The secondary data of this study were the review of previous curriculum of PBI and the policy design of the 2010 Curriculum of PBI obtained from the head of department and have been clarified and verified through a field note by interviewing the relevant stakeholder regarding the conceptions and intentions of the documents

This study involved 35 respondents of different layers, namely the head of department (1 respondent), supervising-teachers (4 respondents) and student-teachers (30 respondents). The main data from the student-teachers were collected through two sets of online survey questionnaires created using "Google Drive" which automatically syncs Sheets directly to the email account. The survey was administered twice; after the completion of teaching round of regular methodology courses and during the first and second month of the teaching-practice period. The data from the supervising-teachers were administered twice; once at the first week of the teachingpractice and the process was repeated in the third week of their teaching-practice. On each occasion, the respondents were asked to indicate their assessment on the student-teachers' teaching-practice using five-level scale of rating in the first part. In the second part, the respondents were asked to provide open-ended feedback for student-teachers.

The data analysis was carried out through the mix of quantitative and qualitative and research method of thematic analysis. ${ }^{29}$ Specifically, the analysis of the survey questionnaires occurred in a recursive and iterative manner. ${ }^{30}$ All the quantitative responses of the student-teachers' survey questionnaires were analyzed using descriptive statistic method; frequency (f), mean score $(\overline{\mathrm{X}})$ and percentage (\%). For qualitative responses (open-ended), they were analyzed in a parallel fashion in relation to similar categories of themes. These open codes that were in the form of specific descriptive phrases were subsequently clustered into broader ideational categories after considerable revision and refinement are subsequently classified as axial and selective coding. 


\section{FINDINGS AND DISCUSSION}

\section{Perceptions and Beliefs of Student-Teachers of Roles and Responsibilities of EFL Teachers}

The study involved a sample of four supervising-teachers and 30 studentteachers with $100 \%$ return rate of questionnaires and feedback sheets. The studentsteachers' scores on the four core methodology courses they have undergone ranged from A-B (Satisfactory-Excellent) before they were asked the efficacy of methodology courses in relation to the improvement of their teaching knowledge and competence in EFL. The finding in the three courses of methodology illustrates the positive acceptance of the student-teachers but not in the last in which they show the attitude of neither agree nor disagree towards the efficacy of the lecture.

The accomplishment of some general and methodology courses in PBI is assumed to be able to improve the student-teachers' academic competence and performance in teaching knowledge, academic English and in understanding roles and responsibilities of professional EFL teachers. The finding shows a normal proportion of capacity level and sense when student-teachers deal with the effects of lectures on their academic competence and performance. This finding also indicates that the majority of the respondents are ready for the next step to their future professional career as they feel to have adequate competence in teaching knowledge, academic English and understanding roles and responsibilities of EFL teachers.

In teaching knowledge area, the respondents were asked to state their estimation of competence they have had after completing all the lectures process in Semester VI. The findings indicate that more than half respondents found lesson planning, classroom control and verbal interaction with learners as their major expertise but they need to learn more in deciding on appropriate teaching strategies, choosing appropriate teaching materials and timing (time management). Lesson planning and teaching materials were presented in CMD while teaching strategies were given in TEFL course. Other areas are in Microteaching course and the theoretical parts of it are provided in TEFL course. The finding to some extent has augured well for the efforts to achieve the objectives of the lectures as stated in the course description that it aims to introduce student-teachers to the key concepts of ELT and get them acquainted with the teaching methods. Besides, student-teachers are given a set of criteria by which critically read, observe, analyze and question approaches and methods and to encourage the student-teachers to develop a reflective approach to teaching.

The respondents' assessment on their own improvement in academic English suggests that their greatest difficulties concerned learning English strategies and macro-skills. Micro-skills can also be problematic while they found acquisition of language elements challenging. These findings are central to the respondents' improvement in understanding roles and responsibilities of EFL teachers. When they have sufficient competence in their academic English, it will not be a much burden for them to be aware of their understanding of roles and responsibilities of EFL teachers. 
The assessment of improvement they have so far in understanding roles and responsibilities of EFL teachers shows the improvement and is congruent to the results showed in the previous result. The respondents' understanding of roles and responsibilities of EFL teachers improve to some extent. However, this matched pattern does not stand alone as a single factor. Another factor is the level of help they have obtained from their lecturers to understand some main aspects in teaching knowledge. The positive tendency of student-teachers' responses on the level of help they have obtained from their lecturers during the lecturing process in campus. The majority of responses were fairly positive and there seemed to be no gaps in the support they were given. The two patterns seem to fairly consistent that when the student-teachers receive enough support, they feel to be fully competent in such area. Also when they believe that they receive some supports (means less than enough), most felt less competent about managing it.

Other factors influence the respondents' responses can be learned more from their suggestions in improvement to see their concurrent situations during the lecture period. Suggestions for the improvement of methodology courses have been tabulated and it provides the major results of the open coding analysis of the respondents' comments in describing instructions they have undergone in their methodology courses.

The most frequent major category referred to in the respondents' comment was the "context". Here the students' language reflected descriptions, interpretations, assumptions, and reports about the context. The focus on the context most emphasized: (1) variety of methods, (2) materials and time management, and (3) course organization. Lesson preparation is the least.

In the concept of method applied in the classroom, the respondents show their disposition to have the theories of all courses implemented directly to school. One course is commented to be outstanding but another course obtains many critics. This course is considered to have a tendency to lack strategies in the process and the respondents hardly accepted that the same method was used in teaching and assessing. This means that such course used the same way of evaluating students from moment to moment.

In materials management, the respondents addressed their critics in two courses; all aspects and inapplicability of content to be used in real teaching. The respondents suggest this course to provide more innovative materials which are appropriate and applicable in real teaching. In time management, the respondents want to have more time to learn more from all courses. In a more specific course, the respondents referred their concern to a more detailed explanation of materials, especially when the lecturer has to teach two subjects subsequently. The most negative disposition is directed to a course in which the time was spent much on talking about useless thing and irrelevant topic regarding the course.

Course organization refers to the need of restructuring the schedule of all courses. For example, the course of Language Testing needs a lecturer who is not in 
duty of teaching another challenging course. In their case, the Language Testing course is taught by a lecturer who also teaches Research Methodology on ELT. Both these courses need a high-level order of thinking that the lecturer should focus on one course only in one semester. For CMD, the respondents also show their need to have this course in two semesters; one is for curriculum block and the other is for materials development block.

The second most frequent major category referred to in the respondents' comment was the "lecturer". Here the students' language reflected descriptions, interpretations, assumptions, and reports about the lecturer. The focus on the lecturer most emphasized: (1) academic competence, (2) teaching responsibility, (3) teaching skills, and (4) language competence. In the lecturers' academic competence, the respondents gave emphasis or detailed clauses on their negative disposition and tended to be general for their positive disposition. In terms of teaching responsibility, the respondents seemed to focus on the lecturers' duty fulfillment, attention to learners' needs and time controlling. In the lecturers' teaching skills, the respondents focus on more specific performance that is assumed to have been learned in some related courses. For example, one of the respondents believed to find out that she never witnessed of any lecturer specify students' learning styles before undergoing learning process. In theory, perhaps she has learned it and it is truly important. The other tended to be normative that the lecturers in three courses should give them more practices to have them confident. There is also a comment that focuses on the lecturers' language competence. The comment indicates the need for all lecturers use English to boost students' interests and confidence, and to avoid a decrease tendency of students' language ability. The third major category referred to in the respondents' comments was the "student". In this last category, the respondents expressed their own feelings about what they have achieved and towards overall teaching process or perhaps commented to avoid silence or emptiness in their sheets, their needs of knowledge of teaching, and thinking skills.

Overall, these findings support the view that qualities of lecturers and teaching as a process variable are a substantial conceptual part of what students remember of both good and poor courses. Since the respondents responded to the question, every one of them had an equal opportunity to elaborate on the lecturer and on other dimensions of what happened in a good and poor PBI course. This also implies that they knew more about, or were more aware of, these dimensions of the course as a process.

\section{Accepted/Rejected Roles and Responsibilities of EFL Teachers Before and After the Teaching-Practice}

This part is about the respondents' level of agreement, showing their attitudes in six predetermined areas of the roles and responsibilities of professional EFL teachers. This agreement is collected before and after their teaching-practice. The researcher used six areas: (1) Student-teachers' beliefs towards learner autonomy, pair/group work, adapting teaching to cater for learner needs, (2) Student-teachers' 
beliefs towards explicit grammar instruction, error correction and native like pronunciation, (3) Technical knowledge, (4) Pedagogical skills, (5) Interpersonal skills, and (6) Personal qualities. The respondents were asked to state their disposition of whether they agree or disagree about the statement. The results of the attitude scale given to student-teachers before and after their teaching practice revealed accumulated finding. Table 17 illustrates the student-teachers' responses on roles and responsibilities of EFL teachers in six areas and with 44 items in total before and after (during) the teaching-practice. The table shows that the majority of student-teachers' attitudinal responses in all areas that begin positive and remain positive (77.73\%). A relatively similar proportion whose responses begin negative but turn to positive $(9.09 \%)$ and begin positive but turn to negative $(8.79 \%)$. Very few of them begin negative and remain negative $(4.39 \%)$.

Table 1. Attitudinal Responses of Student-Teachers (\%)

\begin{tabular}{clccccc}
\hline \multirow{2}{*}{ No. } & Area of Roles and Responsibilities & BARA & BABR & BRBA & BRRR & \multirow{2}{*}{ Total } \\
\cline { 3 - 5 } & $\mathbf{( + / + )}$ & $\mathbf{( + / - )}$ & $\mathbf{( - / + )}$ & $\mathbf{( - / - )}$ & \\
\hline 1 & $\begin{array}{l}\text { Learner autonomy, pair/group work, } \\
\text { adapting teaching to accommodate } \\
\text { learners' needs }\end{array}$ & $52.50 \%$ & $26.67 \%$ & $15.00 \%$ & $5.83 \%$ & $100 \%$ \\
\hline 2 & $\begin{array}{l}\text { Explicit grammar instruction, error } \\
\text { correction and native like pronunciation }\end{array}$ & $67.41 \%$ & $7.41 \%$ & $11.11 \%$ & $14.07 \%$ & $100 \%$ \\
\hline 3 & Technical knowledge & $84.00 \%$ & $4.00 \%$ & $9.33 \%$ & $2.67 \%$ & $100 \%$ \\
\hline 4 & Pedagogical skills & $88.72 \%$ & $4.62 \%$ & $6.15 \%$ & $0.51 \%$ & $100 \%$ \\
\hline 5 & Interpersonal skills & $94.67 \%$ & $0.00 \%$ & $5.33 \%$ & $0.00 \%$ & $100 \%$ \\
\hline 6 & Personal qualities & $86.67 \%$ & $6.67 \%$ & $6.67 \%$ & $0.00 \%$ & $100 \%$ \\
\hline$\quad$ Mean Score (\%) & $\mathbf{7 7 . 7 3}$ & $\mathbf{8 . 7 9}$ & $\mathbf{9 . 0 9}$ & $\mathbf{4 . 3 9}$ & $\mathbf{1 0 0} \%$ \\
\hline & & & & & & \\
\hline
\end{tabular}

Following the table above is the diagram of trajectory that shows a quadrant of the patterns for each pair of student-teachers' attitudes towards roles and responsibilities before and after (during) the teaching-practice. In Pattern 1, the studentteachers' attitude begin positive or accepting the roles and responsibilities of EFL teachers before doing their teaching-practice and remain positive during the teachingpractice. The student-teachers of this pattern are dominant particularly in viewing the area of interpersonal skills, pedagogical skills, personal qualities and technical knowledge that should be embodied by EFL teachers.

In Pattern 2, the student-teachers' attitude begin positive or accepting the roles and responsibilities of EFL teachers before doing their teaching-practice but become negative or rejecting the roles and responsibilities after (during) the teaching-practice. The student-teachers of this attitude pattern are not many but are found to emerge particularly in the area of learner autonomy, pair/group work, adapting teaching to accommodate learners' needs as part of EFL teachers' roles and responsibilities they have to acknowledge. 


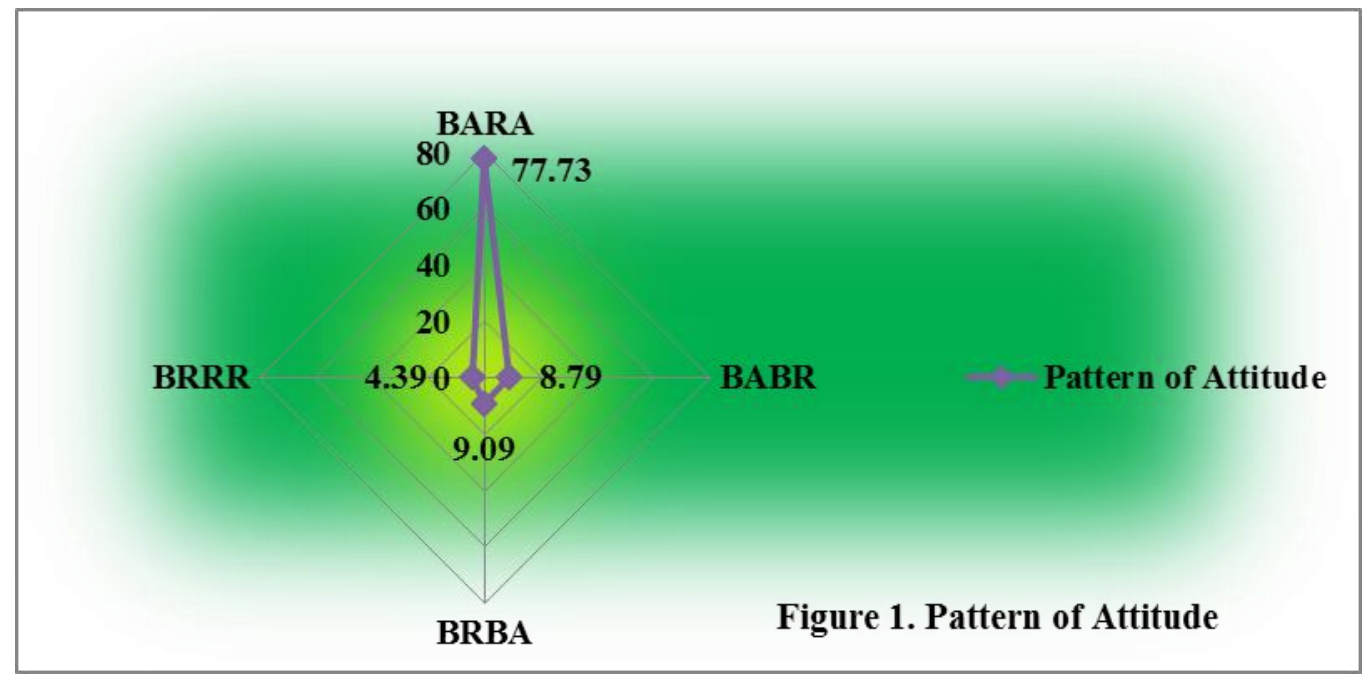

In Pattern 3, the student-teachers' attitude begin negative or rejecting the roles and responsibilities of EFL teachers before doing their teaching-practice but become positive or accepting the roles and responsibilities after (during) the teaching-practice. The student-teachers of this attitude pattern are mainly found in the area of learner autonomy, pair/group work, adapting teaching to accommodate learners' needs but of course they are not the same student-teachers as those in Pattern 2. Another area which this pattern is found to emerge but insignificant is in viewing the importance of explicit grammar instruction, error correction and native like pronunciation.

In Pattern 4, a pattern which is the opposite of Pattern 1 is the minimum type. This pattern shows the student-teachers' attitude that begin negative or rejecting the roles and responsibilities of EFL teachers before doing their teaching-practice and continue to be negative or rejecting the roles and responsibilities after (during) the teaching-practice. The pattern is dominantly found in the way the student-teachers view the unimportance of explicit grammar instruction, error correction and native like pronunciation as part of the EFL teachers' roles and responsibilities towards their students. Overall, they have a tendency to show a consistency in their beliefs and they can be considered as resilient believers or resistant to change. It means that the majority of the student-teachers have internalized their knowledge and used them as the basis of their perception.

\section{Perceptions of Supervising-Teachers on the Student-Teachers of PBI During the Teaching-Practice}

The next finding is dealing with evaluation did by the supervising-teachers on the student-teachers' actual competences in doing their teaching-practice. In all aspects; Assessment, Classroom Management, Content Knowledge, Interpersonal Skills, Meaningful Activities, Pedagogical Competence, Teaching Performance, Preparedness, and Punctuality, except Pedagogical Competence, the student-teachers were rated above 3.50 which mean that they are Highly Dependable. Highly Dependable means that the student-teachers can be relied upon to fulfill their roles and responsibilities with or 
without supervision of the supervising-teachers. Therefore, as the student-teachers always come up on time, do their work efficiently, follow the rules, and remain professional, they are highly dependable. They were also found to be outstanding punctuality/disciplines and preparedness (designing lesson plans). This is probably the most surprising finding from the supervising-teachers as some supervisingteachers modestly admitted that they needed to learn from the student-teachers in the way they designed their lesson plan. This is a compliment that will make the institution proud of the student-teachers' achievement and should be analyzed deeply for further recommendation. However, the student-teachers were found to have problems in five areas, namely the use of English as language of instruction, teaching method, some indications of media use, learning activities and assessment.

\section{CONCLUSIONS AND SUGGESTIONS}

\section{Conclusions}

The student-teachers perceived roles and responsibilities of EFL teachers before and after the teaching-practice differently. Before the teaching-practice, their positive acceptance of roles and responsibilities of EFL teacher subjects to the way the methodology courses are delivered and it is the sign that they are ready for the next step to their future professional career. During the teaching-practice period, they needed longer duration to get more insight into the nature of teaching, to overcome stage fright and develop their own attitude towards teaching, to enable them to get atmosphere in the classroom, and to have more opportunities for self-reflection and for building self-confidence. Overall, the student-teachers perceive that an EFL teacher should be able to do their responsibilities in many areas and involves pedagogic competence, professional competence, social competence and personal competence.

The student-teachers have a tendency to accept learner autonomy, pair/group work, adapting teaching to cater for learner needs before the teaching-practice but tend to decrease their acceptance of some parts of it during the teaching-practice. In other areas, the student-teachers are likely to accept explicit grammar instruction, error correction and native like pronunciation, technical knowledge and interpersonal skills before the teaching-practice and increase the proportion of acceptance during the teaching-practice. The area of pedagogical skills and personal qualities remain accepted equally before and during the teaching-practice.

The student-teachers of PBI UIN Alauddin Makassar have outstanding performance in teaching-practice particularly in designing lesson plans, punctuality, interpersonal skills with students, and personal qualities such as confidence and enthusiasm. The supervising-teachers considered that the student-teachers of PBI UIN Alauddin Makassar still need to improve their English speaking ability, the use of innovative EFL teaching methods and authentic assessment and the use of different kind of teaching media. 


\section{Suggestions}

Review to the curriculum of PBI UIN Alauddin Makassar is urgently needed to accommodate the learning needs and improve the student-teachers' ability to speak English more fluently. It is also urgent to reorganize the methodology courses, putting the emphasis on competence lecturers who are in charge of the courses, the content, and time management.

Review to the teaching-practice program is vital towards the improvement of the student-teachers' capacity as future EFL teachers. The emphasis should be on the time and durations (how many semesters and in which semesters), teaching-practice activities (observation, joined-teaching, independent teaching), attention from tutorlecturers (designing lesson plans, tutoring, monitoring, assessing and evaluating), care from supervising-teachers (mentoring, assisting, monitoring, assessing, evaluating and reporting), evaluation of the two-day preparatory program (which is considered useless so far), and making connection with methodology courses to strengthen the student-teachers' capability in doing their tasks as novice EFL teachers.

Doing a focused-grouped discussion for a more specific research and evaluation on EFL teacher educator program in PBI UIN Alauddin Makassar to understand the problem deeply. It is also important to find more remarkable conceptual strategies in rebuilding the capacity of PBI UIN Alauddin Makassar in providing competent and professional EFL teachers in the future.

\section{ENDNOTES:}

1. Dörneyi, Z. and Murphey, T. Group dynamics in the language classroom. Cambridge: Cambridge University Press, 2003. p. 109.

2. Christiansen, C., and Baum, C. Person-environment-occupational performance: A conceptual model for practice. In C. Christiansen \& C. Baum (Eds.), Occupational therapy: Enabling function and wellbeing (2nd ed., pp. 47-70). Thorofare, NJ: Slack Incorporated. 1997.

3. Richards, Rodgers J.Approaches and Methods in Language Teaching. New York, NY: Cambridge University Press, 2001. P. 24.

4. Littlewood, W. Communicative Language Teaching. Cambridge, UK: Cambridge University Press, 2004. P.92.

5. Harmer, J. The practice of English language teaching. London: Longman, $3^{\text {rd }}$ edition, 2001. and How to teach English. Beijing: Foreign Language Teaching and Research Press, 2003.

6. Tudor, I. Teacher roles in the learner-centred classroom. ELT Journal, 471, 22- 31.1993 and The dynamics of the language classroom. Cambridge: Cambridge University Press, 2003.

7. Undang-Undang RI Nomor 14 Tahun 2005 tentang Guru dan Dosen. And Undang-Undang RI Nomor 20 Tahun 2003 tentang Sistem Pendidikan Nasional.

8. Aberg, A., and Waller, J. “English Language Teachers' Perception of their Role and Responsibility in Three Secondary Schools in Jamaica Engelsklärares syn på deras roll och ansvar vid tre högstadieskolor $i$ Jamaica". Unpublished Research Paper. Jamaica: Lärarutbildningen Engelska och Lärande, 2012.

9. Choudury, A.S. "Classroom roles of English language teachers: The traditional and the innovative İngiliz dili öğretmenlerinin sınıfiçi rolleri: Geleneksel ve yenilikçi." 2011. Contemporary Online Language Education Journal, 2011, 1, pp. 33-40. 
10. Breen M.P. Learner contributions to language learning: New directions in research. Harlow, Essex: Pearson Education Limited. 2001.

11. Schön, D. A. Educating the reflective practitioner: Toward a new design for teaching and learning in the professions. San Francisco: Jossey-Bass, 1987.

12. Brown, J., and McGannon, J. What do I know about language learning? The story of the beginning teacher. 1999. Retrieved September, 20, 2014, from http://www.cltr.uq.edu.au/ alaa/proceed/bro-mcgan.html p. 199.

13. Bruner, J. The culture of education. Cambridge, MA: Harvard University Press. 1996. As discussed in Joram E. and Gabriele, A.J. Preservice teacher beliefs: Transforming obstacles into opportunities. Teaching and Teacher Education 14/2: pp. 175-191. 1998.

14. Holt-Reynolds, D. "Personal history-based beliefs as relevant prior knowledge in course work." American Educational Research Journal, 29, pp. 325-349. 1992 and in Joram E. and Gabriele, A.J. Preservice teacher beliefs: Transforming obstacles into opportunities. Teaching and Teacher Education 14/2: pp. 175-191. 1998.

15. Kwo, O. W. Y. "Towards Reflective Teaching: Curriculum development and Action Research" in D.C.S. Li, D. Mahoney, and J.C. Richards (Eds), Exploring Second Language Teacher Development. Hong Kong: City Polytechnic of Hong Kong, pp.113-130. 1994 p.228.

16. DuBois, D. and Shalin, V.L. Describing job expertise using cognitively-oriented task analysis. 2000. In J.M. Schraagen, S.F. Chipman, \& V.L. Shalin, (Eds.), Cognitive Task Analysis, (pp. 41-56). Mahwah, NJ: Lawrence Erlbaum Associates.

17. Duxa, S. Further Education Events for Teachers of German as a Second Language in Continuing Education and their Impact on the Professionalism of Teachers. Deutsch als Fremdsprache: FaDaF, 2001 p. 66.

18. Hattie, J. Teachers make a difference: What is the research evidence? Australian Council for Educational Research Annual Conference. Auckland: University of Auckland, 2009 p. 35.

19. Schart, M., and Legutke, M. Deutsch Lehren Lernen: Einheit 1, Buch. Berlin: Langenscheidt, 2012.

20. Vineberg, R. and Taylor, E. N. Performance in Four Army Jobs by Men at Different Aptitude (AFQT) Levels: 3. The Relationship of AFQT and Job Experience to Job Performance. Washington, D.C.: Human Resources Research Organization, Alexandria, Office of the Chief of Research and Development, Army, 1972.

21. Peraturan menteri Pendidikan dan Kebudayaan Nomor 87 Tahun 2013. Article 9

22. Brown, J., and McGannon, J. What do I know about language learning? The story of the beginning teacher. 1999. Retrieved September, 20, 2014, from http://www.cltr.uq.edu.au/ alaa/proceed/bro-mcgan.html

23. Almarza G. Student foreign language teacher's knowledge growth. In D. Freeman and J.C. Richards (eds), Teacher Learning in Language Teaching. Cambridge: Cambridge University Press, 50-78. 1996.

24. Schulman, L. Knowledge and teaching: Foundations of the new reform. Harvard Educational Review, 57, 1-12. 1987.

25. Bruner, J. The culture of education. Cambridge, MA: Harvard University Press. 1996.

26. Freeman D. "The hidden side of the work: Teacher knowledge and learning to teach." 2002. Language Teaching 35: p.2.

27. Creswell, J.W. Qualitative inquiry \& research design 2nd ed. Thousand Oaks, CA: Sage, 2007, p. 5.

28. Creswell, J.W. Research design: qualitative, quantitative, and mixed methods approaches (2nd Edition). Thousand Oaks, CA: Sage Publications, 2003 p.111. 
29. Boyatzis, R.E. Transforming qualitative information: Thematic analysis and code development. Thousand Oaks, CA: Sage. 1998 and Ates, B, and Eslami, Z. An analysis of non-native English speaking graduate teaching assistants' online journal entries, Language and Education, 266, 537-552. 2012.

30. Merriam, S.B. Case Study Research in Education: A Qualitative Approach, Jossey-Bass, San Francisco, 1988.

\section{BIBLIOGRAPHY}

Aberg, A., and Waller, J. "English Language Teachers' Perception of their Role and Responsibility in Three Secondary Schools in Jamaica Engelsklärares syn på deras roll och ansvar vid tre högstadieskolor i Jamaica". Unpublished Research Paper. Jamaica: Lärarutbildningen Engelska och Lärande, 2012.

Almarza G. Student foreign language teacher's knowledge growth. In D. Freeman and J.C. Richards (eds), Teacher Learning in Language Teaching. Cambridge: Cambridge University Press, 50-78. 1996.

Ates, B, and Eslami, Z. An analysis of non-native English speaking graduate teaching assistants' online journal entries, Language and Education, 266, 537-552. 2012.

Boyatzis, R.E. Transforming qualitative information: Thematic analysis and code development. Thousand Oaks, CA: Sage. 1998.

Breen M.P. Learner contributions to language learning: New directions in research. Harlow, Essex: Pearson Education Limited. 2001.

Brown, J., and McGannon, J. What do I know about language learning? The story of the beginning teacher. 1999. Retrieved September, 20, 2014, from http://www.cltr.uq.edu.au/alaa/ proceed/bro-mcgan.html

Bruner, J. The culture of education. Cambridge, MA: Harvard University Press. 1996.

Christiansen, C., and Baum, C. Person-environment-occupational performance: A conceptual model for practice. In C. Christiansen \& C. Baum (Eds.), Occupational therapy: Enabling function and wellbeing (2nd ed., pp. 47-70). Thorofare, NJ: Slack Incorporated. 1997.

Choudury, A.S. "Classroom roles of English language teachers: The traditional and the innovative İngiliz dili öğretmenlerinin sınıfiçi rolleri: Geleneksel ve yenilikçi." 2011. Contemporary Online Language Education Journal, 2011, 1, pp. 33-40.

Creswell, J.W. Research design: qualitative, quantitative, and mixed methods approaches (2nd Edition). Thousand Oaks, CA: Sage Publications, 2003.

------. Qualitative inquiry \& research design 2nd ed. Thousand Oaks, CA: Sage, 2007.

Dörneyi, Z. and Murphey, T. Group dynamics in the language classroom. Cambridge: Cambridge University Press, 2003.

DuBois, D. and Shalin, V.L. Describing job expertise using cognitively-oriented task analysis. 2000. In J.M. Schraagen, S.F. Chipman, \& V.L. Shalin, (Eds.), Cognitive Task Analysis, (pp. 41-56). Mahwah, NJ: Lawrence Erlbaum Associates.

Duxa, S. Further Education Events for Teachers of German as a Second Language in Continuing Education and their Impact on the Professionalism of Teachers. Deutsch als Fremdsprache: FaDaF, 2001.

Freeman D. "The hidden side of the work: Teacher knowledge and learning to teach." 2002. Language Teaching 35: 1-13.

Harmer, J. The practice of English language teaching. London: Longman, 3 $3^{\text {rd }}$ edition, 2001.

------. How to teach English. Beijing: Foreign Language Teaching and Research Press, 2003. 
Hattie, J. Teachers make a difference: What is the research evidence? Australian Council for Educational Research Annual Conference. Auckland: University of Auckland, 2009.

Holt-Reynolds, D. "Personal history-based beliefs as relevant prior knowledge in course work." American Educational Research Journal, 29, pp. 325-349. 1992.

Joram E. and Gabriele, A.J. Preservice teacher beliefs: Transforming obstacles into opportunities. Teaching and Teacher Education 14/2: pp. 175-191. 1998.

Kwo, O. W. Y. "Towards Reflective Teaching: Curriculum development and Action Research" in D.C.S. Li, D. Mahoney, and J.C. Richards (Eds), Exploring Second Language Teacher Development. Hong Kong: City Polytechnic of Hong Kong, pp.113-130. 1994.

Littlewood, W. Communicative Language Teaching. Cambridge, UK: Cambridge University Press, 2004.

Merriam, S.B. Case Study Research in Education: A Qualitative Approach, Jossey-Bass, San Francisco, 1988.

Reinmann, G. Promoting Teaching Proficiency in Academic Continuing Education: Initial Situation, Requirements and First Ideas. Deutsch: Preprint, 2011.

Richards, J., and Rodgers, T. Approaches and Methods in Language Teaching. New York, NY: Cambridge University Press, 2001.

Schart, M., and Legutke, M. Deutsch Lehren Lernen: Einheit 1, Buch. Berlin: Langenscheidt, 2012.

Schön, D. A. Educating the reflective practitioner: Toward a new design for teaching and learning in the professions. San Francisco: Jossey-Bass, 1987.

Schulman, L. Knowledge and teaching: Foundations of the new reform. Harvard Educational Review, 57, 1-12. 1987.

Tudor, I. Teacher roles in the learner-centred classroom. ELT Journal, 471, 22- 31. 1993.

------. The dynamics of the language classroom. Cambridge: Cambridge University Press, 2003.

Undang-Undang RI Nomor 14 Tahun 2005 tentang Guru dan Dosen.

Undang-Undang RI Nomor 20 Tahun 2003 tentang Sistem Pendidikan Nasional.

Vineberg, R. and Taylor, E. N. Performance in Four Army Jobs by Men at Different Aptitude (AFQT) Levels: 3. The Relationship of AFQT and Job Experience to Job Performance. Washington, D.C.: Human Resources Research Organization, Alexandria, Office of the Chief of Research and Development, Army, 1972. 